\title{
DETERMINAN PERTUMBUHAN ASET ASURANSI SYARIAH DI INDONESIA
}

\author{
Zubaidah Nasution \\ Program Studi Sarjana Ekonomi Syariah \\ Email: zubaidah@perbanas.ac.id \\ Evi Sistiyarini \\ Program Studi Sarjana Manajemen \\ email: evi.sistiyarini@perbanas.ac.id
}

\begin{abstract}
This study aims to analyze factors influence asset growth of Syariah Insurance in Indonesia. Dependent variable is asset growth. Independent variable are investments, tabarru' fund, claim and insurance premium. Population is all of syaria insurance in Indonesia. Sampling method uses a purposive sampling. There are 10 syaria insurances as samples. Analysis technique uses panel data regression. The results show that investment, tabarru' fund, claim and insurance premium simultaneously have a positive and significance impact to asset growth of sharia insurance in Indonesia. Investment and claim partially have a positive and significance impact to asset growth of sharia insurance in Indonesia. Tabarru' fund has no significant impact to asset growth of sharia insurance in Indonesia. Insurance premium has no a significance impact to asset growth of sharia insurance in Indonesia.
\end{abstract}

Keyword: investment, tabarru', claim, premium, aset 


\section{A. PENDAHULUAN}

Asuransi syariah merupakan kerjasama antara pihak tertanggung dan pihak penanggung dengan kwajiban membayarkan sejumlah premi atas kemungkinan yang akan terjadi kepada tertanggung melalui akad sesuai dengan prinsip syariah. Berdasarkan data dari Asosiasi Asuransi Syariah Indonesia (AASI) 2016 jumlah perusahaan asuransi terbanyak terdapat pada unit syariah asuransi umum dan jiwa masing-masing 24 dan 19 unit syariah. Untuk perusahaan asuransi umum syariah tahun 2016 memiliki 4 perusahaan dan 5 asuransi jiwa. Hal ini terjadi dikarenakan pengenalan masyarakat yang kurang tentang syariah sehingga untuk mengantisipasi risiko perusahaan stakeholder lebih memilih untuk membuka unit asuransi syariah dimana asuransi konvensional sebagai pelindung dalam mengantisipasi kegagalan dari unit syariah perusahaan. Asuransi jiwa syariah, diperkirakan hanya akan bertambah Rp 7,1 triliun di tahun 2017.

Pada tingkat aset, asuransi syariah yakni asuransi jiwa dan asuransi umum tumbuh $21,69 \%$ dari tahun 2015 sampai 2016 . Pertumbuhan yang signifikan terjadi pada asuransi jiwa sebesar 21,82\% dibandingkan asuransi umum sebesar $21,13 \%$. Jika dilihat dari jumlah keseluruhan perusahaan asuransi, unit asuransi umum dan perusahaan asuransi umum syariah memiliki jumlah kantor sebesar 28 asuransi syariah dibandingkan asuransi jiwa sebanyak 24 perusahaan. Hal ini mengindikasikan dengan jumlah aset perusahaan yang banyak asuransi umum belum dapat melakukan pengelolaan aset yang baik dibandingkan asuransi jiwa syariah yang jumlah perusahaannya hanya sebanyak 24 asuransi jiwa dengan pertumbuhan aset $21,82 \%$. Dengan pangsa pasar $6,37 \%$ asuransi jiwa syariah dan $3,74 \%$ asuransi umum dan reasuransi syariah (AASI, 2016).

Investasi merupakan sesuatu yang penting bagi perusahaan. Semakin tinggi hasil investasi maka semakin tinggi pula pertumbuhan asetnya. Istianingsih Sastrodiharjo dan I Putu Sutama (2015) membuktikan bahwa investasi berpengaruh positif signifikan terhadap pertumbuhan aset perusahaan. Dana tabarru' merupakan dana kebajikan yang digunakan untuk menolong peserta. Novi Puspitasari (2012) mengemukakan bahwa dana ini hanya digunakan untuk peserta dan tidak digunakan oleh perusahaan karena perusahaan hanya mengelola dana tersebut saja. Dewi dan Witjaksono (2015) mengemukakan bahwa dana tabarru berpengaruh terhadap pertumbuhan aset.

Klaim merupakan dana yang dibayarkan kepada peserta jika terjadi suatu risiko. Penelitian yang dilakukan oleh Muhammad Ikhsan dkk (2015) dan Faiqotul dkk (2017)membuktikan bahwa klaim berpengaruh signifikan terhadap pertumbuhan aset perusahaan asuransi. Semakin tinggi klaim 
maka semakin rendah pertumbuhan asetnya. Premi merupakan sejumlah dana yang dibayarkan oleh peserta selama periode tertentu kepada perusahaan asuransi. Istianingsih Sastrodiharjo dan I Putu Sutama (2015) dan Shan et al (2016) membuktikan bahwa semakin premi berpengaruh positif terhadap pertumbuhan aset. Semakin tinggi premi yag diterima oleh perusahaan asuransi, maka semakin tinggi pula pertumbuhan asetnya. Akan tetapi hasil tersebut berbeda dengan Faiqotul (2017) yang membuktikan bahwa premi tidak berpengaruh terhadap pertumbuhan aset.

Penelitian tentang pertumbuhan aset baik di perusahaan asuransi atau perusahan non asuransi telah dilakukan oleh beberapa peneliti terdahulu seperti Firdaus dkk (2011), Ida Syafrida dan Ahmad Abror (2011), Istianingsih Sastrodiharjo dan I Putu Sutama (2015), Mukhammad Ikhsan dkk (2015), Faiqotul Nur Assyifah Ainul dkk (2017) yang menunjukkan hasil yang beragam. Oleh karena itu, perlu dilakukan penelitian lebih lanjut tentang determinan pertumbuhan aset asuransi syariah di Indonesia.

Penelitian ini bertujuan untuk mengetahui pengaruh investasi, dana tabarru', klaim dan premi baik secara simultan maupun secara parsial terhadap pertumbuhan aset asuransi syariah di Indonesia.

\section{B. LANDASAN TEORI}

Menurut Undang-Undang No 2 Tahun 1992 menjelaskan bahwa "asuransi adalah perjanjian, antara dua pihak atau lebih dengan mana pihak penanggung mengikatkan diri kepada tertanggung dengan menerima premi asuransi, untuk memberikan penggantian kepada tertanggung karena kerugian, kerusakan, kehilangan keuntungan yang diharapkan atau tanggung jawab hukum kepada pihak ketiga yang mungkin akan diderita tertanggung".

\section{Pertumbuhan Aset}

Aset adalah aktiva atau kekayaan yang dimiliki oleh perusahaan. Aset yang dimiliki perusahaan dapat digunakan untuk kelangsungan kegiatan operasional perusahaan. Dewa Ayu dan Gede Mertha (2017) menyebutkan bahwa pertumbuhan aset sangat diharapkan bagi perkembangan perusahaan secara internal maupun eksternal. Perusahaan yang memiliki pertumbuhan yang tinggi akan memberi tanda bagi perkembangan perusahaan dan memberikan pandangan positif bagi para investor. 


\section{Investasi}

Muhammad Syakir Sula (2004:378) menjelaskan bahwa investasi adalah aktivitas untuk menanamkan atau menempatkan aset, baik berupa harta maupun dana, pada sesuatu yang diharapkan akan memberikan hasil pendapatan atau akan meningkatkan nilainya di masa mendatang. Sedangkan investasi keuangan adalah menanamkan dana pada suatu surat berharga yang diharapkan akan meningkat nilainya di masa mendatang. Investasi keuangan menurut syariah dapat berkaitan dengan kegiatan perdagangan atau kegiatan usaha, di mana kegiatan usaha dapat berbentuk usaha yang berkaitan dengan suatu produk atau aset maupun usaha jasa. Pada prinsipnya, kegiatan pembiayaan dan investasi keuangan dalam asuransi syariah adalah kegiatan yang dilakukan oleh pemilik modal (investor) terhadap pengusaha/pemilik usaha (emiten) untuk memberdayakan pemilik usaha dalam melakukan kegiatan usahanya (Abdullah Amrin, 2006:199).

\section{Dana Tabarru'}

Dana tabarru' terdiri dari dua kata yaitu dana dan tabarru'. Tabarru' berasal dari kata tabarra'a- yatabarra'u- tabarru'an, yang artinya adalah sumbangan, hibah, dana kebajikan atau derma. Orang yang memberikan sumbangan disebut mutabarri' atau dermawan. Definisi tabarru' menurut Jumhur ulama yang dikutip dari Asy-Syarbani al-Khatib adalah akad yang mengakibatkan pemilikan harta, tanpa ganti rugi, yang dilakukan seseorang dalam keadaan hidup kepada orang lain secara sukarela (Muhammad Syakir Sula, 2004: 35)

Dana tabarru ini akan digunakan untuk membantu sesama yang mengalami musibah. Dana klaim yang diberikan diambil dari rekening dana tabarru' yang sudah diniatkan oleh semua peserta ketika akan menjadi peserta asuransi syariah, untuk kepentingan dana kebajikan atau dana tolong-menolong. Pengelolaan dana dalam istilah asuransi adalah cara kerja suatu perusahaan asuransi dalam mengurusi dana premi yang sudah terkumpul dengan cara menginvestasikannya ke lembaga-lembaga keuangan lainnya untuk mendapatkan hasil yang optimal. Pada asuransi syariah, dalam mengelola dana harus sesuai dengan syariah Islam yaitu dengan cara menghilangkan sama sekali kemungkinan terjadi unsur gharar (ketidakpastian), maisir (judi), dan riba.

\section{Klaim asuransi}

Desmadi Hasarudin (2014:132) mengemukakan bahwa klaim merupakan sejumlah dana ganti rugi yang dibayarkan oleh penanggung terhadap tertanggung saat terjadi suatu risiko. Penjelasan mengenai klaim asuransi sangat penting dilakukan oleh pihak asuransi kepada nasabah. 
Hal ini dilakukan agar tidak terjadi penolakan pembayaran klaim akibat kurangnya informasi yang belum diterima oleh nasabah.

\section{Premi asuransi}

Premi merupakan pembayaran sejumlah uang yang dilakukan pihak tertanggung kepada penanggung untuk mengganti suatu kerugian, kerusakan, atau kehilangan keuntungan yang diharapkan akibat timbulnya perjanjian atas pemindahan risiko dari tertanggung kepada penanggung (transfer of risk) (Abdullah Amrin, 2006:108). Menurut fatwa DSN MUI edisi revisi tahun 2006 menjelaskan bahwa premi adalah kewajiban peserta asuransi untuk memberikan sejumlah dana kepada PT asuransi dengan kesepakatan dalam akad. Penyisihan premi yang disetor peserta kepada rekening derma persentasenya ditentukan sesuai dengan kelompok peserta asuransi dan jangka waktu pertanggungan (Ahmad Rodoni, 2015:43)

Muhammad Syakir Sula (2004:311) menjelaskan bahwa unsur premi pada asuransi syariah terdiri dari:

a) unsur tabarru' dan tabungan (untuk asuransi jiwa)

Pada unsur ini, perhitunga perhitungannya diambil dari tabel mortalitas (harapan hidup), yang besarnya tergantung usia dan masa perjanjian. Semakin tinggi usia dan semakin panjang masa perjanjian, maka semakin besar pula nilai tabbaru'. Besarnya premi asuransi jiwa yang pada asuransi syariah disebut tabbaru' berada pada kisaran 0,75 sampai 12 persen.

b) unsur tabbaru' saja (untuk asuransi kerugian dan term insurance pada life). Besarnya tabbaru' pada asuransi kerugian merujuk ke rate standard yang dibuat oleh DAI (Dewan Asuransi Indonesia).

Abbas Salim (2005:46) juga mengklasifikasikan premi pada asuransi syariah menjadi tiga bagian yaitu:

a) Premi tabungan yaitu premi yang disetor oleh pemegang polis untuk dipergunakan sesuai keperluan masing-masing pemegang polis.

b) Premi biaya yaitu sejumlah uang yang dibayarkan peserta asuransi untuk membayar biaya administrasi dan operasional.

c) Premi tabarru' yaitu sejumlah uang yang dibayarkan oleh pemegang polis atau peserta asuransi secara ikhlas dan tidak untuk dimintta kembali ditunjukkan tolong menolong. Premi ini disbeut juga premi proteksi pada asuransi. Premi tabarru' bukan menjadi hak milik perusahaan, bila perusahaan tidak lagi menjalankan usahnaya maka saldo dana tabarru' dikembalikan kepada umat untuk berbagai aktifitas kebajikan. 
Perusahaan asuransi juga memperhatikan penetapan besarnya tarif premi. Hal ini dilakukan agar premi yang dibayarkan oleh nasabah nantinya akan dapat menutup klaim serta biaya-biaya asuransi.

\section{Pengaruh antar variabel \\ Pengaruh Investasi Terhadap Pertumbuhan Aset}

Semakin tinggi kemampuan suatu perusahaan dalam mengelola investasi yang dimiliki, maka semakin tinggi pula pertumbuhan aset perusahaan. Hasil investasi yang baik akan mendorong perusahaan untuk terus meningkatkan jumlah asetnya. Selain itu, investasi yang meningkat dapat memberikan sinyal positif bagi para investor perusahaan. Penelitian yang dilakukan oleh Istianingsih Sastrodiharjo dan I Putu Sutama (2015) berhasil membuktikan bahwa nilai keuntungan investasi berpengaruh positif pada pertumbuhan aset perusahaan asuransi jiwa. Beberapa perusahaan asuransi lebih memilih melakukan investasi yang memiliki tingkat return yang lebih tinggi untuk dapat memberikan kontribusi terhadap pertumbuhan asetnya. Faiqotul dkk (2017) juga memberikan bukti bahwa investasi berpengaruh signifikan terhadap pertumbuhan aset pada perusahaan asuransi.

Ha1 : Investasi berpengaruh positif signifikan terhadap pertumbuhan aset asuransi syariah di Indonesia.

\section{Pengaruh Dana Tabarru' Terhadap Pertumbuhan Aset}

Dana tabarru' merupakan dana yang digunakan untuk pengeluaran asuransi syariah yaitu klaim. Dana tabbaru' ini merupakan dana yang akan diinvestasikan sehingga apabila klaim tinggi maka akan menurunkan jumlah dana yang akan diinvestasikan sehingga akan mempengaruhi hasil investasi. Pada akhirnya hasil investasi kecil. Semakin kecil investasinya maka pertumbuhan aset perusahaan juga akan kecil (Dewi dan Witjaksono, 2015). Novi Puspitasari (2012) mengungkapkan bahwa dana tabarru' bahwa dana ini merupakan dana yang dikumpulkan oleh peserta untuk kegiatan tolong menolong. Semakin tinggi dana tabarru' maka semakin rendah kemampuan perusahaan dalam meningkatkan asetnya sehingga pertumbuhan aset juga semakin menurun.

Ha2 : Dana tabarru' berpengaruh negatif signifikan terhadap pertumbuhan aset pada asuransi umum syariah. 


\section{Pengaruh Klaim Terhadap Pertumbuhan Aset}

Klaim merupakan sejumlah dana yang dibayarkan kepada tertanggung atas terjadinya kerugian/kerusakan yang dialami oleh tertanggung sesuai dengan perjanjian dengan penanggung. Semakin tinggi tingkat klaim yang diajukan oleh tertanggung, maka semakin besar pula dana yang dikeluarkan oleh perusahaan asuransi. Hal ini mengindikasikan bahwa biaya yang dikeluarkan oleh perusahaan asuransi semakin besar. Besarnya biaya/beban yang dikeluarkan oleh perusahaan akan mengurangi kemampuan perusahaan untuk berinvestasi dalam bentuk aset sehingga berdampak pada menurunnya pertumbuhan aset. Oleh karena itu, klaim berpengaruh negatif terhadap pertumbuhan aset. Penelitian yang dilakukan oleh Muhammad Ikhsan dkk (2015) membuktikan bahwa klaim berpengaruh signifikan terhadap pertumbuhan aset perusahaan asuransi. Faiqotul dkk (2017) juga memberikan bukti bahwa klaim berpengaruh terhadap pertumbuhan aset pada perusahaan asuransi.

Ha3 : Klaim berpengaruh negatif signifikan terhadap pertumbuhan aset asuransi syariah di Indonesia.

\section{Pengaruh Premi Terhadap Pertumbuhan Aset}

Premi merupakan sejumlah uang yang dibayarkan oleh tertanggung kepada penanggung atas kemungkinan kerugian yang akan dialami oleh tertanggung. Semakin besar premi yang dibayarkan oleh tertanggung, maka semakin besar dana yang yang diterima oleh perusahaan asuransi berupa pendapatan premi. Dana yang diterima ini kemudian akan diinvestasikan oleh perusahaan asuransi dalam bentuk aset. Sehingga semakin tinggi premi yang diterima oleh perusahaan asuransi maka semakin tinggi pula kemampuan perusahaan dalam menambah aset perusahaan. Oleh karena itu premi berpengaruh positif terhadap pertumbuhan aset. Istianingsih Sastrodiharjo dan I Putu Sutama (2015) dan Shan et al (2016) dalam penelitiannya berhasil membuktikan bahwa premi merupakan faktor penting yang berpengaruh terhadap pertumbuhan aset perusahaan asuransi. Faiqotul dkk (2017) memberikan hasil yang berbeda yaitu premi tidak berpengaruh terhadap pertumubuhan aset pada perusahaan asuransi.

Ha4 : Premi berpengaruh positif signifikan terhadap pertumbuhan aset asuransi syariah di Indonesia

\section{METODE PENELITIAN Jenis Data Penelitian}

Penelitian ini merupakan jenis penelitian asosiatif yang bertujuan untuk mengetahui hubungan antara dua variabel atau lebih (V. Wiratna 
Sujarweni, 2015: 46). Penelitian ini menggunakan sumber data sekunder berupa laporan keuangan masing-masing perusahaan asuransi syariah serta data yang berasal dari website Otoritas Jasa Keuangan (OJK).

\section{Populasi dan Sampel}

Populasi penelitian ini adalah seluruh perusahaan asuransi syariah yang ada di Indonesia. Terdapat 24 perusahaan asuransi umum syariah dan 19 perusahaan asuransi jiwa syariah. Pemilihan sampel diambil dengan menggunakan metode purposive sampling berdasarkan ketentuan yaitu perusahaan asuransi jiwa syariah yang terdaftar dan memiliki laporan keuangan secara lengkap mulai tahun 2011 sampai dengan 2016. Berdasarkan pemilihan sampel tersebut diperoleh 10 perusahaan yang menjadi sampel penelitian.

\section{Definisi Operasional dan Pengukuran Variabel}

Variabel-variabel penelitian yang digunakan dalam penelitian ini meliputi variabel terikat (variabel dependen) dan variabel bebas (variabel dependen).

a. Variabel Dependen

Variabel dependen yang digunakan dalam penelitian ini adalah pertumbuhan aset.

Pertumbuhan aset dapat diukur dengan menggunakan rumus sebagai berikut (Istianingsih dan I Putu, 2015).

$$
\text { Pertumbuhan Aset }=\frac{\text { Aset tahun ke } \mathrm{t}-\text { Aset tahun ke } \mathrm{t}-1}{\text { Aset Tahun ke } \mathrm{t}-1}
$$

b. Variabel Independen

Variabel Independen dalam penelitian ini terdiri dari:

(1) Investasi (X1)

Investasi merupakan suatu kegiatan untuk menempatkan dana dalam bentuk aset dengan tujuan untuk memperoleh keuntungan lebih di masa yang akan datang. Investasi pada penelitian ini diukur dengan menggunakan rumus sebagai berikut (Istianingsih dan I Putu, 2015):

Retun investasi $=$ hasil investasi

(investasi tahun $_{\mathrm{t}}-$ investasi tahun $_{\mathrm{t}-1}$ )/2

(2) Dana Tabarru' (X2)

Dana tabarru' merupakan dana kebajikan atau tolong menolong yang digunakan untuk membayar klaim nasabah asuransi syariah. Pada penelitian ini dana tabarru' diukur dengan melihat jumlah dana secara keseluruhan nasabah (Novi Puspitasari, 2012).

(3) Klaim (X3) 
Klaim merupakan pembayaran ganti rugi antara nasabah dengan perusahaan asuransi syariah di Indonesia mulai tahun 2011 sampai dengan tahun 2016. Pada penelitian ini klaim pada perusahaan asuransi syariah diukur dengan menggunakan total klaim yang diperoleh dari laporan keuangan pada satu periode (Yusuf, T dan Dansu, F., 2014).

(4) Premi (X4)

Premi merupakan sejumlah dana yang disetor oleh tertanggung kepada penanggung perusahaan asuransi syariah di Indonesia mulai tahun 2011 sampai dengan tahun 2015. Pada penelitian ini, premi dapat diukur dengan menggunakan rasio pertumbuhan premi dengan formulasi sebagai berikut (Istianingsih dan I Putu, 2015).

Pertumbuhan Premi $=\frac{\text { Premi tahun ke } t-\text { Premi tahun ke } \mathrm{t}-1}{\text { Premi Tahun ke } \mathrm{t}-1} \mathbf{3 . 4}$

\section{Analisis Regresi Data Panel}

Metode analisis yang digunakan dalam penelitian ini adalah analisis regresi data panel. Analisis regresi data panel adalah analisis regresi dengan struktur data merupakan data panel. Data panel merupakan gabungan data cross section dengan time series. Dalam regresi data panel terdapat 3 (tiga) bentuk model, yaitu Pooled OLS Model (PLS), Fixed Effect Model (FEM), dan Random Effect Model (REM). Prosedur pengujian untuk memilih model mana yang paling tepat adalah sebagai berikut.

(i) Uji statistik Chow, digunakan untuk memilih antara model PLS atau model FEM dengan rumus sbb:

$$
F=\frac{\left(S S R_{1}-S S R_{2}\right) /(n-1)}{S S R_{2} /(n T-n-k)}
$$

Dimana, $\mathrm{n}=$ jumlah individu; $\mathrm{T}=$ jumlah periode waktu; $\mathrm{k}=$ jumlah parameter dalam model FEM (tidak termasuk intersep); $\mathrm{SSR}_{1}$ dan $\mathrm{SSR}_{2}$ masing-masing merupakan sum square residual teknik tanpa variabel dummy (PLS) dan teknik FEM dengan variabel dummy. Nilai statistik $F$ hitung akan mengikuti distribusi statistik $F$ dengan derajat bebas (df) sebanyak n-1 untuk numerator dan sebanyak nT-n-k untuk denumerator. Jika nilai statistik $F$ hitung lebih besar daripada $F$ tabel pada tingkat signifikansi tertentu, maka dapat disimpulkan model FEM lebih tepat daripada model PLS.

(ii) Uji Langrange Multiplier (LM), digunakan untuk memilih antara model PLS atau model REM, dengan rumus sbb :

$$
L M=\frac{n T}{2(T-1)}\left[\frac{\sum_{i=1}^{n}\left(\sum_{t=1}^{T} e_{i t}\right)^{2}}{\sum_{i=1}^{n} \sum_{t=1}^{T} e_{i t}^{2}}-1\right]^{2}
$$




$$
=\frac{n T}{2(T-1)}\left[\frac{\sum_{i=1}^{n}\left(T \bar{e}_{i}\right)^{2}}{\sum_{i=1}^{n} \sum_{t=1}^{T} e_{i t}^{2}}-1\right]^{2}
$$

Dimana, $\mathrm{n}=$ jumlah individu; $\mathrm{T}=$ jumlah periode waktu dan $\mathrm{e}_{\text {it }}$ adalah residual metode PLS. Uji LM ini didasarkan pada distribusi Chi-square dengan derajat bebas (df) sebesar 1. Jika hasil LM statistik lebih besar dari nilai kritis statistik chi-square, maka dapat disimpulkan model REM lebih tepat daripada model PLS.

(iii) Uji Hausman, digunakan untuk memilih antara model FEM atau model REM, dengan rumus sbb:

$$
W=\left[\hat{\beta}-\hat{\beta}_{G L S}\right]^{-1}\left[\hat{\beta}-\hat{\beta}_{G L S}\right] \sim \chi_{(k)}^{2}
$$

Statistik uji Hausman di atas, mengikuti distribusi statistik chi-square dengan derajat bebas sebanyak $k$, dimana $k$ adalah jumlah variabel independen. Jika nilai statistik Hausman lebih besar daripada nilai kritis statistik chi-square, maka dapat disimpulkan model FEM lebih tepat daripada model REM.

\section{Pengujian Asumsi Klasik}

Uji asumsi klasik dilakukan pada penelitian ini. Uji asumsi klasik ini terdiri dari uji normalitas, uji multikolinearitas, uji autokorelasi dan uji heteroskedastisitas.

a. Uji Normalitas

Uji normalitas bertujuan untuk menguji apakah dalam sebuah regresi, variabel dependen dan variabel independen atau keduaduanya mempunyai distribusi yang normal atau tidak. Uji normalitas ini dilakukan dengan melihat grafik histogram, normal probability plots, dan Kolmogorov-Smirnov Test (Imam Ghozali, 2006:110-115).

b. Uji Multikolinearitas

Uji multikolinearitas bertujuan untuk menguji apakah di dalam model regresi ditemukan adanya korelasi antar variabel independen. Cara untuk mendeteksi ada tidaknya multikolinearitas di dalam model regresi yaitu sebagai berikut (Imam Ghozali,2006: 95):

1) Nilai $R 2$ yang dihasilkan oleh model regresi sangat tinggi, tetapi secara individu variabel independen banyak yang tidak mempengaruhi variabel dependen. 
2) Melihat nilai tolerance dan nilai variance inflation factor (VIF). Nilai cutoff yang dipakai untuk menunjukkan adanya multikolinearitas adalah nilai tolerance $\leq 0,10$ atau VIF $\geq 10$.

c. Uji Autokorelasi

Uji autokorelasi digunakan untuk mengetahui apakah terjadi korelasi antara kesalahan pengganggu pada periode $t$ dengan kesalahan pada periode $t-1$ (periode sebelumnya) (Imam Ghozali, 2006:100). Pengujian ini menggunakan model Durbin Watson Test (DW test). Jika nilai Dw lebih besar dari upper bound (du) dan kurang dari 4-du (du < dw < 4-du), maka tidak terdapat autokorelasi dalam model persamaan regresi (Gujarati Damodar, 2006: 122).

d. Uji Heteroskedastisitas

Uji heteroskedastisitas digunakan untuk mengetahui apakah dalam model regresi terjadi ketidaksamaan variance dari residual satu pengamatan ke pengamatan yang lain (Imam Ghozali, 2006:125). Uji ini dapat dilakukan dengan melihat grafik scatter plot antara nilai prediksi variabel (ZPRED) dengan nilai residualnya SRESID.

\section{Pengujian Hipotesis}

\section{a. Uji F (Uji pengaruh secara simultan)}

Uji F-statistik digunakan untuk mengetahui apakah semua variabel independen memiliki pengaruh secara simultan terhadap variabel dependen (Imam Ghozali, 2006:88). Adapun langkah-langkah pengujian yang dilakukan yaitu:

1) Menentukan Ho dan $\mathrm{Ha}$

Ho : $\beta_{1}=\beta_{2}=\beta_{3}=\beta_{4}=0$

Berarti variabel independen secara simultan berpengaruh tidak signifikan terhadap variabel dependen.

$\mathrm{Ha}: \beta_{1} \neq \beta_{2} \neq \beta_{3} \neq \beta_{4} \neq 0$

Berarti variabel independen secara simultan berpengaruh signifikan terhadap variabel dependen.

2) Membandingkan tingkat signifikansi dengan $\alpha=5 \%$ serta membandingkan $F$ hitung dengan $F$ tabel. Jika nilai sig $>$ a $5 \%$ dan nilai $\mathrm{F}$ hitung > F tabel, maka $\mathrm{Ha}$ diterima yang berarti bahwa variabel independen (Xi) secara simultan berpengaruh signifikan terhadap variabel dependen $(\mathrm{Y})$. Jika nilai sig $<5 \%$ dan nilai $\mathrm{F}$ hitung $<\mathrm{F}$ tabel, maka Ho diterima yang menunjukkan bahwa variabel independen ( $\mathrm{Xi}$ ) secara simultan berpengaruh tidak signifikan terhadap variabel dependen $(Y)$.

b) Uji t Statistik (Uji Pengaruh Parsial)

Uji t-statistik digunakan mengetahui secara parsial pengaruh variabel independen terhadap variabel dependen (Imam Ghozali, 
2006: 88). Berikut ini adalah langkah-langkah yang dapat dilakukan daalam uji t statistik:

1) Menentukan $\mathrm{Ho}$ dan $\mathrm{Ha}$

Ho: $\beta_{1}=\beta_{2}=\beta_{3}=\beta_{4}=0$

Hal ini berarti bahwa variabel independen secara parsial berpengaruh tidak signifikan terhadap variabel dependen.

$\mathrm{Ha}: \beta_{1} \neq \beta_{2} \neq \beta_{3} \neq \beta_{4} \neq 0$

Hal ini berarti bahwa variabel independen secara parsial berpengaruh signifikan terhadap variabel dependen.

2) Membandingkan nilai signifikansi dengan $\alpha=5 \%$ serta membandingkan $t_{\text {hitung }}$ dengan $t_{\text {tabel }}$. Jika nilai sig $>\alpha 5 \%$ dan nilai $t_{\text {hitung }}$ $>t_{\text {tabel }}$ maka $\mathrm{Ha}$ diterima yang artinya variabel independen $(\mathrm{Xi})$ secara parsial berpengaruh terhadap variabel dependen $(Y)$. Jika nilai sig $<\alpha$ $5 \%$ dan nilai $t_{\text {hitung }}<t_{\text {tabel }}$ maka Ho diterima yang artinya bahwa variabel independen $(\mathrm{Xi})$ secara parsial tidak berpengaruh terhadap variabel dependen $(Y)$.

c) Koefisien Determinasi $\left(\mathbf{R}^{2}\right)$

Koefisien determinasi $\left(\mathrm{R}^{2}\right)$ digunakan untuk mengukur kemampuan variabel independen dalam menjelaskan variabel dependen. Semakin tinggi nilai koefisien determinasi ini menunjukkan bahwa kemampuan variabel independen semakin baik dalam menjelaskan variabel dependennya (Imam Ghozali, 2006: 87).

\section{HASIL DAN PEMBAHASAN}

\section{Uji Normalitas}

Uji normalitas pada penelitian bertujuan untuk menguji apakah dalma model regresi, variabel pengganggu atau residual memiliki distribusi normal. Jumlah data sebanyak 60 data, akan tetapi terdapat beberapa data outlier sehingga data outlier tersebut dihilangkan dalam proses pengolahan data dan total $\mathrm{N}$ sebanual 53 data. Hasil uji normalitas dapat dilihat pada tabel 1.

Tabel 1. Hasil Uji Normalitas

One-Sample Kolmogorov-Smirnov Test

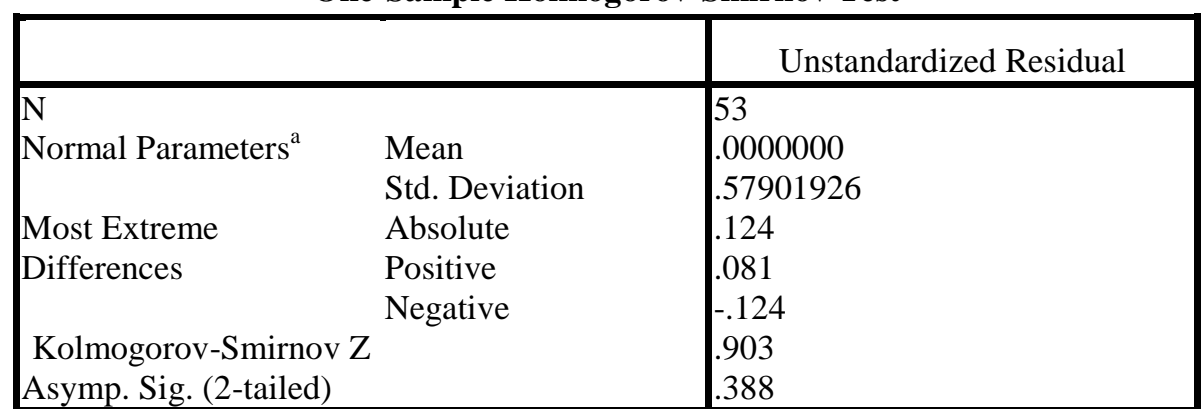

Sumber: data diolah (2017) 
Berdasarkan hasil uji normalitas, nilai residual yang ditunjukkan dari sig. Kolmogorov-Smirnov sebesar 0,388 dengan taraf signifikansi 0,05 dengan demikian dapat disimpulkan data terdistribusi secara normal.

\section{Uji Asumsi Klasik}

Uji Multikoloneritas

Tabel 2. Coefficient Correlation

\begin{tabular}{|l|c|c|c|c|}
\hline & DANA & & \\
& INVESTASI & $\begin{array}{c}\text { TABARRU' } \\
\text { KALAIM }\end{array}$ & PREMI \\
\hline INVESTASI & 1.000000 & -0.261986 & 0.577303 & 0.616110 \\
\hline DANA & & & & \\
\hline TABARRU' & -0.261986 & 1.000000 & 0.237081 & 0.248483 \\
\hline KLAIM & 0.577303 & 0.237081 & 1.000000 & 0.945591 \\
\hline PREMI & 0.616110 & 0.248483 & 0.945591 & 1.000000 \\
\hline
\end{tabular}

Sumber : Data diolah (2017)

Dari hasil analisis pada menunjukkan bahwa VIF untuk investasi dengan dana tabarru' sebesar 0,269186 investasi dengan klaim sebesar 0,577303 investasi dengan premi sebesar 0,616110, dana tabarru' dengan investasi sebesar -0,261986, dana tabarru' dengan klaim sebesar 0,237081 dana tabarru' dengan premi 0.248483 , klaim dengan investasi 0,57703 , klaim dengan dana tabarru' 0,237081 , klaim dengan premi 0,945591 . Selanjutnya premi dengan investasi 0,616110 , premi dengan dana tabarru' 0,248483 , premi dengan klaim 0,945591. Pada nilai VIF kurang dari 10 dan nilai tolerance lebih dari 0,1 maka dapat disimpulkan model regresi dari masing-masing variabel tidak terjadi multikoloneritas.

\section{Uji Heterokedastisitas}

Hasil uji heterokedastisitas dapat dilihat pada tabel di bawah ini

Tabel 3. Hasil Uji Heterokedastisitas

Dependent Variable: RESABS

Method: Panel EGLS (Cross-section random effects)

Sample: 20112016

Total panel (unbalanced) observations: 53

Swamy and Arora estimator of component variances

Variable $t \quad$ Std. Error t-Statistic Prob. 


\begin{tabular}{lcccc}
\hline \hline C & 0.993103 & 0.486990 & 2.039268 & 0.0469 \\
INVESTASI & -0.0213470 .048165 & -0.443213 & 0.6596 \\
DANA & -0.0202820 .023541 & -0.861564 & 0.3932 \\
KLAIM & 0.112353 & 0.065494 & 1.715483 & 0.0927 \\
PREMI & -0.1143010 .063496 & -1.800138 & 0.0781 \\
\hline \hline \multicolumn{4}{c}{ Mean } & dependent0.33448 \\
R-squared & 0.123626 & var & 2 \\
Adjusted & R- & & 0.38817 \\
squared & 0.050595 & S.D. dependent var 5 \\
& & & 6.85545 \\
S.E. of regression & 0.377918 & Sum squared resid & 5 \\
& 1.692789 & Durbin-Watson stat 6 & 1.92650 \\
F-statistic & 0.167113 & & \\
Prob(F-statistic) & & & \\
\hline
\end{tabular}

Sumber : Data diolah (2017)

Dari hasil uji regresi, tabel diatas menunjukkan bahwa probabilitas signifikansi masing-masing variabel independen diatas 0,05 secara statistik tidak mempengaruhi variabel dependen absolute maka dapat disimpulkan model regresi diatas tidak terjadi Heterokedastisitas

\section{Uji Autokorelasi}

Berdasarkan uji regresi diperoleh nilai durbin-watson test sebesar 1,834, diperoleh nilai dL sebesar 1,414 dan dU sebesar 1,724. Nilai DW test lebih besar dari batas atas (du) sebesar 1,724 dan kurang dari 4-du sebesar 2,276 maka dapat disimpulkan bahwa tidak ditolak H0 atau dapat disimpulkan tidak ada autokorelasi positif dan negatif.

\section{Analisis Regresi Berganda}

Hasil analsisis regresi berganda dapat dilihat pada tabel 4. 
Tabel 4. Hasil Analisis Regresi Berganda

\begin{tabular}{|c|l|l|l|}
\hline Variabel & \multicolumn{1}{|c|}{ Coefficient } & t-Statistic & Prob. \\
\hline C & 5.678086 & 7.806984 & 0.0000 \\
\hline INVESTASI & 0.453740 & 6.169436 & 0.0000 \\
\hline DANA & 0.003977 & 0.112155 & 0.9112 \\
\hline KLAIM & 0.299229 & 3.007347 & 0.0042 \\
\hline PREMI & -0.139698 & -1.453473 & 0.1526 \\
\hline R-squared & 0.770717 & \\
Adjusted R-squared & 0.751610 & \\
F statistic & 40.33701 & \\
Prob(F-statistic) & 0.000000 & & \\
\hline
\end{tabular}

Sumber : Data diolah (2017)

Berdasarkan hasil uji lagrangage multiplier (LM) nilai LM pada hitung data panel sebesar 0,421>0,05. Jika hasil LM statistik lebih besar dari nilai kritis statistik chi-square atau taraf signifikansi maka dapat disimpulkan model Random Effect lebih tepat daripada Common model. Hasil analisis regresi variabel investasi, dana tabarru', klaim dan premi terhadap pertumbuhan aset asuransi syariah Indonesia tahun 2011 sampai 2016. Nilai $R$ squared sebesar 0,771 menunjukkan bahwa variasi variabel investasi, dana tabarru', klaim dan premi dapat dijelaskan sebesar $77 \%$ dari variabel aset sisanya $23 \%$ dijelaskan oleh variabel lain. Pada adjusted R-squared nilainya sebesar 0,751 atau 75\% diman alebih rendah dari $\mathrm{R}$ squared sebesar 0,771 atau $77 \%$. Secara parsial atau uji $t$ variabel investasi dan klaim berpengaruh signifikan dengan taraf signifikansi 5\% dan variabel dana tabarru' dan premi tidak berpengaruh signifikan dengan taraf signifikan 5\%. Model regresi uji $\mathrm{F}$ dilihat dari probabilitas F-statistik sebesar 0,000 atau 0\% menunjukkan hasil yang berpengaruh secara simultan dengan taraf signifikansi 0,05 atau 5\%.

Berdasarkan hasil uji secara parsial tingkat signifikansi investasi sebesar 0,0000 dan nilai koefisien sebesar 0.453 maka Ha diterima artinya investasi berpengaruh positif dan signifikan terhadap pertumbuhan aset asuransi syariah. Koefisien sebesar 0.453740 mengartikan bahwa setiap kenaikan investasi sebesar $1 \%$ dengan asumsi koefisien variabel lain tetap maka akan berdampak pada kenaikan pertumbuhan aset sebesar $0.45374 \%$.

Dana tabarru' memiliki nilai signifikansi sebesar 0,9112 dan nilai koefisien sebesar 0.003977 maka Ha ditolak artinya dana tabarru' tidak berpengaruh signifikan terhadap pertumbuhan aset asuransi syariah. Koefisien sebesar 0,003977 mengartikan bahwa setiap kenaikan dana 
tabarru' sebesar 1\% dengan asumsi koefisien variabel lain tetap maka akan meningkatkan pertumbuhan aset sebesar 0,003977\%.

Klaim memiliki nilai signifikansi sebesar 0,00412 dan nilai koefisien sebesar 0,299229 maka Ha diterima artinya klaim berpengaruh positif dan signifikan terhadap pertumbuhan aset. Koefisien sebesar 0,299299 mengartikan bahwa setiap kenaikan klaim sebesar 1\% dengan asumsi koefisien variabel lain tetap akan meningkatkan pertumbuhan aset sebesar 0,299299\%

Premi memiliki nilai signifikansi sebesar 0,1526 dan nilai koefisien sebesar -0,139698 maka Ha ditolak artinya premi tidak berpengaruh signifikan terhadap pertumbuhan aset asuransi syariah. Koefisien sebesar $-0,139698$ menunjukkan bahwa setiap kenaikan premi sebesar $1 \%$ dengan asumsi koefisien variabel lain tetap akan menurunkan pertumbuhan aset asuransi syariah sebesar 0,139698\%.

\section{Pembahasan Hasil Penelitian}

Hasil penelitian menunjukkan bahwa klaim memiliki pengaruh positif signifikan terhadap pertumbuhan aset bank syariah di Indonesia. Investasi merupakan salah satu kegiatan yang dilakukan oleh perusahaan untuk menempatkan dananya dengan tujuan untuk mencari keuntungan. Semakin tinggi hasil investasi yang diperoleh perusahaan maka dapat memberikan sebuah sinyal positif bahwa di perusahaan memiliki kinerja yang baik di masa yang akan datang. Hal ini akan dapat mendorong perusahaan asuransi untuk meningkatkan investasinya di berbagai pos sehingga pertumbuhan aset perusahaan asuransi juga ikut meningkat. Hasil penelitian ini sejalan dengan penelitian yang dilakukan oleh Istianingsih Sastrodiharjo dan I Putu Sutama (2015) dan Faiqotul dkk (2017) yang menunjukkan bahwa hasil investasi berpengaruh positif terhadap pertumbuhan aset perusahaan asurannsi.

Dana tabarru' tidak berpengaruh signifikan terhadap pertumbuhan aset bank syariah di Indonesia. Hasil yang tidak signifikan ini dikarenakan dana tabarru' merupakan dana kebajikan yang diberikan oleh nasabah secara ikhlas dan dapat digunakan untuk membantu salah satu nasabah. Perusahaan asuransi menggunakan dana ini untuk hal-hal kebaikan seperti membayar klaim kepada tertanggung. Dengan arti lain bahwa perusahaan asuransi akan lebih mengutamakan dana ini untuk membantu sesama umat manusia daripada untuk keperluan perusahaan dalam menghasilkan keuntungan. Oleh karena itu, dana tabarru' tidak memberikan pengaruh yang signifikan terhadap pertumbuhan aset. Hasil penelitian ini tidak sejalan dengan penelitian yang dilakukan oleh (Dewi dan Witjaksono, 2015) yang membuktikan bahwa dana tabarru memiliki pengaruh negatif terhadap pertumbuhan aset perusahaan asuransi. 
Klaim berpengaruh positif signifikan terhadap pertumbuhan aset. Hasil ini tidak sesuai dengan teori bahwa klaim berpengaruh negatif terhadap pertumbuhan aset. Secara teori, Semakin tinggi tingkat klaim yang diajukan oleh tertanggung, maka semakin besar pula dana yang dikeluarkan oleh perusahaan asuransi. Hal ini mengindikasikan bahwa biaya yang dikeluarkan oleh perusahaan asuransi semakin besar. Besarnya biaya/beban yang dikeluarkan oleh perusahaan akan mengurangi tingkat investasi dalam bentuk asset. Sehingga pertumbuhan aset perusahaan juga akan menurun. Hasil penelitian menunjukkan bahwa semakin tinggi klaim yang dibayarkan maka semakin tinggi pertumbuhan asetnya. Hasil penelitian ini sejalan dengan penelitian yang dilakukan oleh Muhammad Ikhsan dkk (2012) dan Faiqotul dkk (2017) yang membuktikan bahwa klaim tidak berpengaruh terhadap pertumbuhan aset perusahaan asuransi.

Premi tidak berpengaruh signifikan terhadap pertumbuhan aset. Premi adalah sejumlah dana yang dibayarkan oleh tertanggung kepada penanggung atas kemungkinan terjadinya risiko di masa yang akan datang. Semakin tinggi premi yang dibayarkan kepada perusahaan asuransi syariah maka semakin rendah pertumbuhan aset perusahaan asuransi. Ketidaksignifikanan ini terjadi karena premi ini dipersiapkan untuk membayar dana klaim kepada nasabah/tertanggung, bukan untuk keperluan asuransi dalam meningkatkan asetnya. Hasil penelitian ini tidak mendukung penelitian yang dilakukan oleh Istianingsih Sastrodiharjo dan I Putu Sutama (2015) dan Shan et al (2016) yang membuktikan bahwa premi merupakan faktor penting yang berpengaruh terhadap pertumbuhan perusahaan asuransi. Akan tetapi penelitian ini sejalan dengan penelitian yang dilakukan oleh Faiqotul dkk (2017) yang membuktikan bahwa premi tidak berpengaruh terhadap pertumbuhan aset perusahaan asuransi.

\section{E. KESIMPULAN}

Hasil penelitian menunjukkan bahwa Investasi, Dana tabarru', premi dan klaim secara simultan berpengaruh terhadap pertumbuhan aset asuransi syariah di Indonesia. Investasi secara parsial memiliki pengaruh positif yang signifikan terhadap pertumbuhan aset asuransi syariah di Indonesia. Dana tabarru' dan premi secara parsial tidak berpengaruh terhadap pertumbuhan aset asuransi syariah di Indonesia. Sedangkan klaim secara parsial memiliki pengaruh positif signifikan terhadap pertumbuhan aset asuransi syariah di Indonesia

\section{IMPLIKASI}

Penelitian ini memberikan implikasi teoritis dan praktis. Secara teoritis, hasil penelitian ini memberikan mendukung hasil teori tentang 
pertumbuhan aset. Namun ada beberapa hasil penelitian yang bertentangan dengan teori. Secara praktis penelitian ini dapat digunakan sebagai pertimbangan bagi perusahan asuransi syariah untuk meningkatkan pertumbuhan asetnya.

\section{SARAN}

\section{Bagi Perusahan Asuransi}

1) Bagi perusahaan asuransi syariah, dapat meningkatkan kegiatan investasi namun juga perlu mempertimbangkan risiko yang dihadapi saat melakukan investasi.

2) Bagi perusahaan asuransi syariah, pengelolaan terhadap dana klaim juga sangat diperlukan.

\section{Bagi Peneliti Selanjutnya}

1) Bagi peneliti selanjutnya diharapkan dapat menambah jumlah variabel penelitian serta dapat memasukkan faktor eksternal perusahaan.

2) Bagi peneliti selanjutnya diharapkan dapat menambah jumlah periode penelitian.

\section{KETERBATASAN}

Keterbatasan penelitian ini adalah ada beberapa data penelitian yang tidak lengkap di laporan keuangan asuransi syariah.

\section{REFERENSI}

Abbas Salim. 2005. Asuransi Dan Manajemen Risiko. Jakarta: PT Raja Grafindo Persada.

Abdullah Amrin. 2006. Asuransi Syariah: Keberadaan dan Kelebihannya di Tengah Asuransi Konvensional. Jakarta: IKAPI.

Ahmad Rodoni. 2015. Asuransi dan Pegadaian Syariah. Jakarta: Mitra Wacana Media

Asosiasi Asuransi Syariah Indonesia. 2016. Data Bisnis Asuransi dan Reasuransi Syariah Q1 2016. (http://aasi.or.id, diakses 25 Oktober 2016)

Desmadi Saharuddin. 2014. Pembayaran Ganti Rugi pada Asuransi Syariah. Jakarta: Prenada Media Grup

Dewa Ayu Intan Yoga Maha Dewi, Gede Mertha Sudiartha. 2017. Pengaruh Profitabilitas, Ukuran Perusahaan, Dan Pertumbuhan Aset Terhadap Struktur Modal dan Nilai Perusahaan, E-Journal Manajemen Unud, 6(4), 2222-22252. 
Dewan Syariah Nasional MUI, Himpunan Fatwa Dewan Syariah Nasional MUI, Edisi Revisi 2006, No 21/DSN-MUI/X/2001, Tentang Pedoman Umum Asuransi Syariah

Dewi, K, V., dan Witjaksono, A. 2015. Evaluasi Pengakuan Pendapatan dan Beban Atas Dana Tabbaru' dan Dana perusahaan pada Asuransi PT ajb BumiPutera 1912. Jurnal. Binus University.

Faiqotul Nur A, Jeni Susyanti, Ronny Malavia M. 2017. Pengaruh Premi, Klaim, Hasil Underwriting, Investasi dan Profitabilitas Terhadap Pertumbuhan Aset Pada Perusahaan Asuransi Jiwa Syariah di Indonesia. E-Journal Riset Manajemen. 97-110

Firdaus Djaelani, Jeremias T. Keban, Suad Husnan dan Mamduh Hanafi. 2011. "Pertumbuhan Asuransi Jiwa di Indonesia: Suatu Kajian dari Sisi Penawaran”. Jurnal Kawistara, Vol.1, No.3.

http://www.infobanknews.com diakses tanggal 25 Oktober 2016

Ida Syafrida dan Ahmad Abror. 2011. "Faktor-Faktor Internal dan Eksternal yang Mempengaruhi Pertumbuhan Aset Perbankan Syariah di Indonesia". Jurnal Ekonomi dan Bisnis. Vol. 10, No 1. pp 19-24.

Imam Ghozali. 2006. Aplikasi Analisis Multivariate dengan Program SPSS.

Yogyakarta: Badan Penerbit Universitas Diponegoro

Ismanto Kuat. 2009. Asuransi Syariah (Tinjauan Asas-Asas Hukum Islam). Yogyakarta: Pustaka Belajar

Istianingsih dan I Putu. 2015. Faktor-Faktor yang Mempengaruhi Pertumbuhan Aset Perusahaan Asuransi Jiwa Non Syariah di Indonesia. Jurnal Akuntabilitas, 8(1), 18-38.

Muhammad Ikhsan, Asep Ramdan \& Epi Fitriah. 2015. Pengaruh Premi dan Klaim Terhadap Pertumbuhan Aset pada PT. Asuransi Sinarmas Syariah Tahun 2013-2014. Prosiding Keuangan dan Perbankan Syariah, ISSN: 2460-2159.

Muhammad Syakir Sula. 2004. Asuransi Syariah (Life and General). Jakarta: Gema Insani.

Novi Puspitasari. 2012. Model Proporsi Tabarru' dan Ujrah pada Bisnis Asuransi Umum Syariah di Indonesia,. Jurnal Akuntansi dan Keuangan Indonesia, 9(1), 43-55. 
Shan, Lee., Teng, Kevin., Kai dan Chuan. 2016. Growth Opportunity of Insurance and Its Determinants in The Selected Countries of Asean. International Business Managemen. Vol 17, 3892-3898.

Undang-Undang Nomor 2 Tahun 1992 Tentang Usaha Perasuransian.

Yusuf, T dan Dansu, F. 2014. "Effect of Claim Costs On Insure's Profitability In Nigeria". International Journal of Business and Commerce. Vol. 3 No 10. pp 01:20. 